\title{
Community Service Program on Empowerment of Village Community in Karangnongko Village, Karangnongko Subdistrict, Klaten Regency, Republic of Indonesia
}

\author{
$1^{\text {st }} \mathrm{E}$ Wardani \\ Department of Management \\ Universitas Widya Dharma \\ Klaten, Republic of Indonesia \\ emawardani1000@gmail.com \\ $4^{\text {th }}$ E E D Setiawati \\ Department of English Education \\ Universitas Widya Dharma \\ Klaten, Republic of Indonesia
}

\author{
$2^{\text {nd }}$ A J S Nugroho \\ Department of Management \\ Universitas Widya Dharma \\ Klaten, Republic of Indonesia
}

\author{
$5^{\text {th }}$ S R Widayanti \\ Department of English Education \\ Universitas Widya Dharma \\ Klaten, Republic of Indonesia
}

\author{
$3^{\text {rd }}$ M P Darmo \\ Department of Civil Program \\ Universitas Widya Dharma \\ Klaten, Republic of Indonesia
}

\begin{abstract}
The KKN (Community Service Program)PPM (Community Service Center) activity in Karangnongko Village, Klaten Regency aims to improve the Tourism Village management system, increase community participation in the development of the family economy, so as to provide new jobs for housewives to increase community income and grow the village economy. Models of activities carried out include: 1) Entrepreneurship Capacity Building and 2) Technology Transfer. To be able to achieve these objectives, several activity plans are proposed in the implementation of the KKN-PPM Program in Karangnongko Village as follows: a) Establishment of Tourism Village Management Institution b) Establishment of a new marketing network (distribution channel) of Tourism Village (c) Training and development of local crafts and d) Provision of supporting facilities / infrastructure for the development of Karang Nongko Tourism Village. From the activities it is obtained positive result that the community is enthusiastic to take part in the program and lead to the formation of the foundation of village tourism and entrepreneurship empowerment in the village community environmentThe KKN (Community Service Program)-PPM (Community Service Center) activity in Karangnongko Village, Klaten Regency aims to improve the Tourism Village management system, increase community participation in the development of the family economy, so as to provide new jobs for housewives to increase community income and grow the village economy. Models of activities carried out include: 1) Entrepreneurship Capacity Building and 2) Technology Transfer. To be able to achieve these objectives, several activity plans are proposed in the implementation of the KKN-PPM Program in Karangnongko Village as follows: a) Establishment of
\end{abstract}

Tourism Village Management Institution b) Establishment of a new marketing network (distribution channel) of Tourism Village (c) Training and development of local crafts and d) Provision of supporting facilities / infrastructure for the development of Karang Nongko Tourism Village. From the activities it is obtained positive result that the community is enthusiastic to take part in the program and lead to the formation of the foundation of village tourism and entrepreneurship empowerment in the village community environment.

Keywords-Community Service Program, Village Community, Klaten Regency

\section{INTRODUCTION}

Karangnongko Village, Karangnongko Subdistrict, Klaten Regency has a variety of economic potential that can be used as a capital in developing a tourism village. The diversity of this potential is a strength and opportunity for the development of a Tourism Village. If the strengths and opportunities are not planned and not managed properly, it is possible that these strengths and opportunities will become weaknesses and challenges[1]. Tourism potential that is not yet well known and has not yet been raised to the surface needs to be explored and inventoried to be managed and designed as a tourist attraction. This requires a good knowledge and understanding and synergy between several related parties / stakeholders in the process of community empowerment [2]. Village communities must play a greater role because they know in detail about the tourism potential they have. 
This potential can be made in a package as a tourist attraction [3].

Most of the people in Karangnongko Village have low education background, namely elementary and junior high school graduates. Many of them are the elderly with the majority of professions as farmers. In Karangnongko Village there are 2 ancient temples namely Merak Temple and Karangnongko Temple. Due to the weakness of community resources around the temple, they do not yet have a way on the development of the temple tourism village. Much remains to be optimized in the two temples in order to be a tourist attraction. Tour Packages of Temple Trekking and farming community culture can be realized into the potential to become a tourism package. Thus, all existing potential, both natural potential, cultural potential, human resource potential and spiritual potential can be managed with a local wisdom management system [4]. All direct to positive benefits for Karangnongko Village including its conservation activities.

Behind the existing potential certainly it requires a special management and handling so that the potential has a positive impact on the community. Efforts to manage the potential of Karangnongko Village to be developed as a Tourism Village still encounter obstacles / problems such as: a) A Community-Based Management Institution has not been formed to manage the potential of a Tourism Village b) The ability of human resources need to be trained and enhanced in order to become the main actors in the management of Tourism Villages, c) There are still many villagers who are not yet economically independent so entrepreneurship training is needed.

To overcome these problems, several proposals submitted in the implementation of the KKN-PPM program in Karangnongko Village are as follows:

a) Establish a Karangnongko Tourism Village Management Institution, b) Invent village tourism potential, c) Prepare tourism packages of village excellence such as temple trekking, village life and local culinary, and d) Develop mothers' spirit of entrepreneurial skills to make local souvenirs that reflect the identity of Karangnongko Village

\section{ACTIVITY METHOD USED}

Taking into account the outputs / results of the activities, the methods used to overcome the problem can be classified into two, namely: data on village tourism potential and community empowerment programs. To achieve the target output, the following methods are carried out: a) Data collection through field surveys; b) Empowerment program through counseling, training and assistance, namely regular meetings between the mentor and the target group. The approach taken includes: Entrepreneurship Capacity Building Model and Technology Transfer [5].

\section{A. Entrepreneurship Capacity Building (ECB) Model}

This model is used to improve the entrepreneurial abilities of rural communities. The program is carried out through empowerment and assistance. The University functions as a motivator, innovator, facilitator, and communicator.

\section{B. Technology Transfer Model}

The findings of research results and / or other activities from university are applied to the community appropriately. Furthermore, appropriate technology training will be carried out in various sectors including the tourism sector and microeconomics. Several institutions have been designated as partners in the implementation of the KKN-PPM Program: a) Tourism Awareness Group of Karangnongko Village, b) Dasa Wisma (ten house) Group of Karangnongko Village and c) Karangnongko Village Government. The three partner institutions are the supporting components of the Karangnongko Village community involved in the planning and development of the Tourism Village [6].

\section{Target and Output}

- Improvement and enhancement in the Tourism Village Management System by forming a Tourism Village Management Institution whose task is to plan, manage, market and to operate the Tourism Village Package. This activity was organized through training for tourism resources and carried out continuous evaluations.

- Enhancement of community's active participation in the development of Tourism Villages. Community participation in this case involves the involvement and participation in the management and implementation of operational activities in the implementation of the Tourism Village Package.

- Enhancement of community's ability to realize the Vision and Mission of the Klaten Regency Government in developing the Tourism Village in Karangnongko Subdistrict so that it is increasingly known by tourists.

- Increase of income received by housewives as the target group from the development of the Tourism Village in Karangnongko,

\section{RESULTS OF ACTIVITIES}

The program activity steps have been carried out to achieve the expected results of the KKN-PPM theme in Karangnongko Village: a) Establishment of the Management Institution of Tourism Village in Karangnongko Village, b) A new activity of Tourism Village package has been implemented in the form of internet media activities to be offered to tourists. These activities include something to see, something to do, something to buy, and something to learn c) Preparation of farmland / farmer group farms as an agro tourism activity site, d) Preparation of residents' homes as a place to stay for tourists, e) Preparation of local culinary of typical Karangnongko Village, f) An increase of competence in the field of tourism, especially for the target group through English language training for village youth, g) A tour package for temple trekking and village life has been set. This activity involves various components of the Karangnongko Village community. The paths for trekking activities are arranged and packaged in such a way. The beauty and appeal of the two temples in Karangnongko Village can be seen directly. 
This activity can also maintain the individuals' health and fitness h). Entrepreneurship Socialization which aims to introduce and motivate mothers in the village to have an entrepreneurial spirit and be able to get their own income. Mothers and teenage girls are very enthusiastic in conducting discussions on entrepreneurship suitable to all the time without any season restrictions.
Practice activities and entrepreneurship training for mothers include

- Making handicrafts from flannel to be brooch. With this activity the mothers in the village have a high enthusiasm to utilize the knowledge from students so that it can be created into high-quality handicraft items, attractive for sale and get income for the household economy.

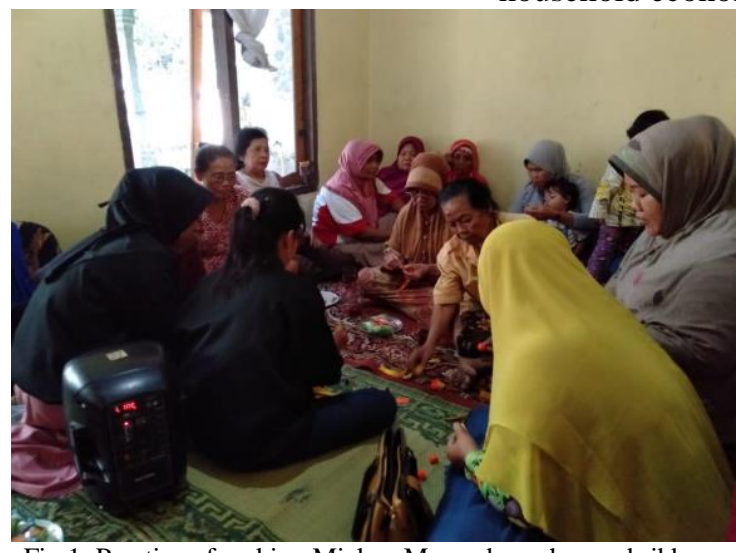

Fig.1. Practice of making Mickey Mouse brooches and ribbons

- $\quad$ Making a sleeping lamp from threads and balloons. It is very difficult and requires high concentration in team work. Even though it looks difficult, it doesn't make mothers give up. The output of activities depends on individual skills. The more diligent the work is the end result will be more unique and interesting.

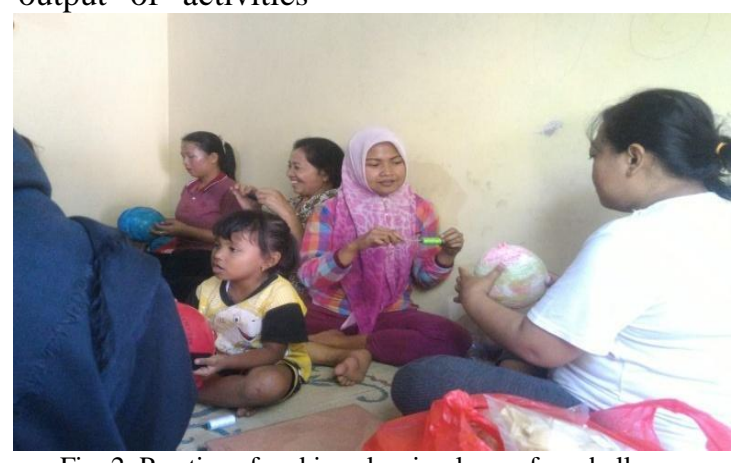

Fig. 2. Practice of making sleeping lamps from balloons

- Socialization of the Utilization of Plastic Waste, the socialization and utilization of plastic waste aims to reduce plastic waste by utilizing used bottles for making decorative pots. This program attracts mothers to use used items such as bottles and oil packaging to be used as valuables. This activity can also reduce plastic pollution in the Karangnongko Village environment.

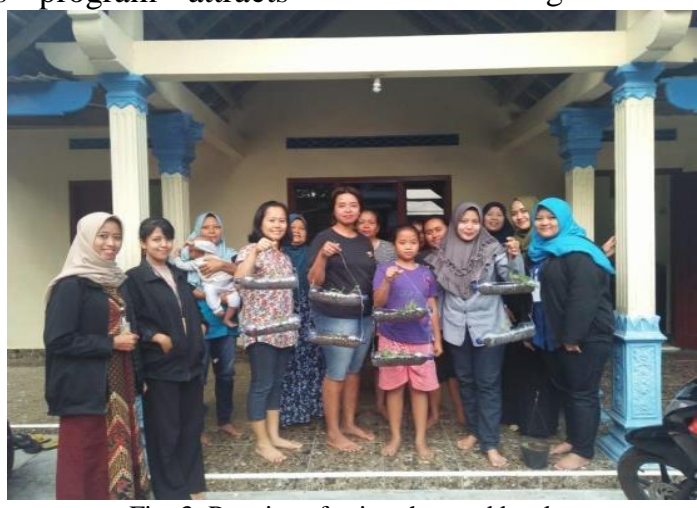

Fig. 3. Practice of using the used bottles

\section{CONCLUSIONS}

From the above activities, it can be concluded that Community Service Program on Community
Empowerment in Karangnongko Village, Klaten Regency get a positive response from the community and the Klaten Regency government. The results achieved include 
strengthening of the tourism village institution in Karangnongko Village, strengthening of the network, increasing of the variety of tourism activities that can be presented, increasing of promotional activities and creating of the entrepreneurial spirit of the villagers.

The development of a Tourism Village in Karangnongko Village, Klaten Regency is not enough to be done in a short time, but requires a long and continuous time. Therefore, to ensure the sustainability of the program, continuous accompaniment must be carried out [7]. It can be done either by the University or by involving partners. Active participation of the Karangnongko Village community as the main actor in the activities of the Tourism Village Package activities must continue.

\section{ACKNOWLEDGMENT}

Universitas Widya Dharma Klaten for the 2019 Applied Community Building Scheme Grant

\section{REFERENCES}

[1] Dangi, Tek B, Jamal Tazim 2016 An Integrated Approach to Sustainable Community Based Tourism, Sustainability Journal, Sustainability 8475

[2] Mendez, E.M, Balaguer, J.G, Merigo J.M, Forteza C.M 2018, sustainable Tourism research Towards twenty five years of the journal of Sustainable Tourism, Advances in Hospitality and Tourism Research

[3] Prayudi. 2018 Study on Stakeholder Engagement and Communication in Developing Sustainable Tourism in Indonesia, People: International Journal of Social Sciences 4 (3) $574-592$

[4] Linan, Fransico et.al. 2011. Factors Affecting Entrepreneurial Intention Levels:a Role for Education. International Entrepreneur Management Journal. 7:195-218

[5] Kaur, Rajwinder, 2014. Innovation and Entrepereneurship: Relational Aspect, Internatioal Journal of Business and Administration research Review, 1:95): 93-98

[6] Putra, Agus Muriawan. 2006. Konsep Desa Wisata, Jurnal Manajemen Pariwisata, ISSN No. 1412 - 1263. Denpasar: STIE

[7] Wahyuni D, Siswoyo B.S, Witjaksono M. 2016 The Development Strategy of Ecopreneurship Based Tourism Vilage, The Development Research of the Tourism Village in Desa Wonomerto Wonosalam Jombang, International Confrence on Education for Economics pp 2540-8372 